\title{
Alkylphenols in Surface Sediments of the Gulf of Gdansk (Baltic Sea)
}

\author{
Iga Koniecko - Marta Staniszewska • Lucyna Falkowska • \\ Dorota Burska • Joanna Kielczewska • Anita Jasinska
}

Received: 7 March 2014 / Accepted: 18 June 2014 / Published online: 24 July 2014

(C) The Author(s) 2014. This article is published with open access at Springerlink.com

\begin{abstract}
The widespread use of alkylphenols in European industry has led to their presence in the environment and the living organisms of the Baltic Sea. The present study (2011-2012) was designed to determine the concentrations of alkylphenols, 4-nonylphenol (NP) and 4-tert-octylphenol (OP), in surface sediments of the Gulf of Gdansk, a section of the Baltic that lies in close proximity to industrial and agricultural areas and borders with an agglomeration of nearly one million inhabitants. It is also where the Vistula, the largest Polish river, ends its course. In spring, large concentrations of 4-nonylphenol and 4-tert-octylphenol were washed off into the coastal zone with meltwater. In summertime, sediments near the beach had the highest alkylphenol concentrations (NP-2.31 $\mathrm{ng} \mathrm{g}^{-1} \mathrm{dw}, \mathrm{OP}-13.09 \mathrm{ng} \mathrm{g}^{-1}$ $\mathrm{dw}$ ), which was related to tourism and recreational activity. In silt sediments located off the coast, the highest NP (1.46 $\left.\mathrm{ng} \mathrm{g}^{-1} \mathrm{dw}\right)$ and OP (6.56 $\left.\mathrm{ng} \mathrm{g}^{-1} \mathrm{dw}\right)$ amounts were observed in autumn. The origin of $\mathrm{OP}$ and $\mathrm{NP}$ at those test stations was linked to atmospheric
\end{abstract}

Highlights Alkylphenols and black carbon reach the Gulf of Gdansk through rivers and via the atmosphere.

4-tert-octylphenol was found in sediments in higher concentrations than 4-nonylphenol.

The sediments of the Gulf of Gdansk (Baltic Sea) are not badly polluted with alkylphenols.

I. Koniecko $\cdot$ M. Staniszewska $(\bowtie) \cdot$ L. Falkowska

D. Burska $\cdot$ J. Kielczewska $\cdot$ A. Jasinska

Institute of Oceanography, University of Gdansk,

Al. Marszalka Pilsudskiego 46, 81-378 Gdynia, Poland

e-mail: marta.staniszewska@ug.edu.pl transport of black carbon along with adsorbed alkylphenols.

Keywords 4-nonylphenol · 4-tert-octylphenol . Organic carbon · Black carbon in sediments · Gulf of Gdansk · Southern Baltic

\section{Introduction}

4-nonylphenol (NP) and 4-tert-octylphenol (OP) belong to a category of compounds that are capable of mimicking the hormones of living organisms and thus disrupting their hormonal balance. They influence the synthesis, transportation, bonding, action or excretion of hormones that occur naturally in the system and are responsible for maintaining homeostasis as well as for reproduction or the behaviour of a living organism (US EPA 2010).

Phenol derivatives can imitate the action of the sex hormone $17 \beta$-estradiol. The estrogenicity of alkylphenols was discovered as early as the 1930s. First tests to be conducted by Dodds and Lawson in 1938 showed that a 100-mg dose of 4-propylphenol administered to female rats with surgically removed ovaries resulted in changes in their reproductive system that were characteristic of the estrous cycle, despite the fact that they were lacking in estradiol (Markey et al. 2001). NP exhibits an endocrine-disrupting action which is three times as strong as DDT. Additionally, 4nonylphenol and 4-tert-octylphenol are both acutely 
toxic to fish, invertebrates and algae (Servos 1999; Flint et al. 2012).

Due to their lipophilic characteristics, 4-nonylphenol and 4-tert-octylphenol can combine with both live and dead organic matter in water and in bottom sediments. According to a research carried out by Ying et al. (2003), 4-tert-octylphenol and 4-nonylphenol have the highest degree of sorption on sediment particles compared to bisphenol $\mathrm{A}$ and hormones such as $17 \beta-$ estradiol (E2) and 17 $\alpha$-ethinyl estradiol (EE2).

Alkylphenyl ethoxylates (precursors of alkylphenols) have been used in industry for over 50 years. Nearly $80 \%$ of all alkylphenyl etoxylates currently produced are nonylphenol etoxylates. 4-nonylphenol is used mainly in the production of surface active agents, while 4-tert-octylphenol is used for the production of synthetic materials (HELCOM 2011). Alkylphenols 100,000 tonnes are produced in Europe every year, accounting for one-third of the global production, and in 2001, EU production of 4-tert-octylphenol amounted to 23,000 tonnes. There are 12 major producers of octylphenols in Europe. Russia produces 17,000 tonnes of octylphenol every year (HELCOM 2011). The main producer of nonylphenol in Poland is PCC Synteza SA in Kedzierzyn-Kozle (about 12,000 tons every year).

The Gulf of Gdańsk, situated in the south part of the Baltic Sea, is exposed to contaminants like alcylphenols (Staniszewska and Falkowska 2011; Staniszewska et al. 2014). There is very little available information on alkylphenol concentrations in the sediments of the Baltic Sea. According to HELCOM, the highest OP and NP concentrations were detected in the central area of the Baltic and in the Danish straits region, where concentrations exceeded $10.2 \mathrm{ng} \mathrm{g}^{-1} \mathrm{dw}$ (OP) and $540 \mathrm{ng} \mathrm{g}^{-1} \mathrm{dw}(\mathrm{NP})$, whereas the lowest concentrations of both alkylphenols were found in the sediments of the Gulf of Finland and Gulf of Bothnia (HELCOM 2010).

The aim of the present study was to establish the concentrations of 4-nonylphenol and 4-tert-octylphenol in the surface sediments of the Gulf of Gdansk as well as to determine the spatial and temporal variability of the compounds' concentrations. A particular focus was placed on indicating potential external sources of alkylphenols in the Gulf of Gdansk, hence the situation of test stations at sea along the coastline from the estuary of the Vistula river, the second largest river in the Baltic drainage basin, and close to the outlets of several smaller rivers measuring between 10 and $20 \mathrm{~km}$ each. The possibility of alkylphenols arriving to the Gulf of
Gdansk via atmospheric transportation from local and distant sources was analysed, taking into account the presence of organic carbon (OC) and black carbon (BC) in surface sediments.

\section{Materials and Methods}

\subsection{Sample Collection}

Sediment samples were collected in 2011 and 2012 in three different seasons (spring, summer and autumn). Seven coastal stations were used, and, of these, three were located by river outlets: the Vistula (ST1), the Kacza (ST2) and the Gizdepka (ST6), while the other four were situated near urbanised areas: Orlowo Pier (ST3), the Seaside Boulevard in Gdynia (ST4), Mechelinki (ST5), Swarzewo (ST7). Five more stations were located at sea further away from the coastline, below the 4-m isobath: ME, GDY, SP, GN, UW (Table 1) (Fig. 1).

Five-centimetre-thick layers of sediment were collected using a core sampler. Samples were frozen until the time of analysis and subsequently lyophilized. The following physicochemical properties were determined in the sediment samples: wetness (W), loss-on-ignition (LOI), total carbon (TC), organic carbon (OC), black carbon $(\mathrm{BC})$ and granulometric composition.

\section{Methods}

\subsection{Physicochemical Properties}

The wetness of sediments was determined by measuring the mass of wet sediment and then the dry mass after an approximately 24-h drying session at $105{ }^{\circ} \mathrm{C}$. Granulometric analysis was performed by sieving dry sediment through a set of metal sieves of the following net dimensions: $2.00,1.00,0.5,0.125,0.063 \mathrm{~mm}$. Losson-ignition was determined as a change of dry sediment mass after igniting at $550{ }^{\circ} \mathrm{C}$ until constant mass was reached (Heiri et al. 2001). All carbon types were determined using a PerkinElmer CHNS/O Analyzer through combustion of a dry sediment sample. Organic carbon was analysed using the chemothermal oxidation method (Gustafsson et al. 1997), the sample having previously been acidified in order to remove carbonates (Hedges and Stern 1984). When analysing black carbon, an 
Table 1 The characteristics and location of sediment sample collection sites

\begin{tabular}{|c|c|c|c|c|c|}
\hline \multirow{2}{*}{\multicolumn{3}{|c|}{ collection sit }} & \multirow{3}{*}{$\begin{array}{l}\text { Station symbol/ } \\
\text { Station name }\end{array}$} & \multirow{3}{*}{ Characteristics } & \multirow{3}{*}{ Location } \\
\hline & & & & & \\
\hline \multirow{2}{*}{$\begin{array}{l}\text { Station symbol/ } \\
\text { Station name }\end{array}$} & \multirow[t]{2}{*}{ Characteristics } & \multirow[t]{2}{*}{ Location } & & & \\
\hline & & & $\mathrm{GN}$ & Station located $19 \mathrm{~km}$ to the & $54^{\circ} 31.70^{\prime} \mathrm{N}$ \\
\hline \multirow[t]{2}{*}{$\begin{array}{l}\text { Vistula } \\
\text { Swibno }\end{array}$} & \multirow{2}{*}{$\begin{array}{l}\text { The Vistula is the main } \\
\text { source of pollutants } \\
\text { flowing from the whole of } \\
\text { Poland into the Baltic Sea. } \\
\text { Measuring } 1,047 \mathrm{~km} \text {, it } \\
\text { orioinates in the mountains }\end{array}$} & \multirow{2}{*}{$\begin{array}{l}\text { Pontoon } \\
\text { bridge on } \\
\text { the Vistula }\end{array}$} & & $\begin{array}{l}\text { North-West of the Vistula } \\
\text { estuary, } 37 \mathrm{~m} \text { below sea level. }\end{array}$ & $\begin{array}{l}18^{\circ} 50.30^{\prime} \\
\mathrm{E}\end{array}$ \\
\hline & & & $\mathrm{ME}$ & $\begin{array}{l}\text { Station located about } 1 \mathrm{~km} \text { away } \\
\text { from the coast, } 4 \mathrm{~m} \text { below sea } \\
\text { level. }\end{array}$ & $\begin{array}{l}54^{\circ} 36.44^{\prime} \mathrm{N} \\
18^{\circ} 31.59^{\prime} \\
\mathrm{E}\end{array}$ \\
\hline
\end{tabular}

ST2 Kacza River The river flows through Gdynia

$(14.8 \mathrm{~km})$. Drainage area

$\left(53.8 \mathrm{~km}^{2}\right)$ densely covered

with bushes and woods

interspersed with small areas

of marshy meadows and

peatland. The main sources of

pollutants are the nearby

urbanised areas.

ST3 Orlowo Pier

Wooden pier located in

Gdynia by the Kacza river

outlet and close to

recreational beaches.

ST4 Gdynia Seaside adjacent to a marina and Boulevard the city beach of Gdynia, is a recreational site, frequented by tourists and locals alike.

ST5 Mechelinki Recreational site, the beach in Mechelinki.

ST6 Gizdepka The river flows in a narrow River

ST7 Swarzewo ravine across agricultural areas. The main source of pollution is surface run-off from cultivated fields and farms. The river, measuring $11.8 \mathrm{~km}$, ends its course in Puck Bay near Oslonino.

Holiday destination on Puck Sea coast Bay, featuring a water purification plant.

UW

SP

Station located $7 \mathrm{~km}$ to the North- $54^{\circ} 25.90^{\prime} \mathrm{N}$ East of the Vistula estuary, $40 \mathrm{~m} \quad 18^{\circ} 58.80^{\prime}$ below sea level.

$\mathrm{E}$

Station located $7 \mathrm{~km}$ away from $54^{\circ} 28.91^{\prime} \mathrm{N}$ Orlowo Pier, $17 \mathrm{~m}$ below sea $18^{\circ} 40.43^{\prime}$ level.

E

Station located $4 \mathrm{~km}$ away from $54^{\circ} 32.80^{\prime} \mathrm{N}$ the entrance to Gdynia Harbour, $12 \mathrm{~m}$ below sea level.
Table 1 (continued)

additional stage was implemented following carbonate removal and consisted of ignition at $375{ }^{\circ} \mathrm{C}$ for $18 \mathrm{~h}$ with constant air flow.

\subsection{Alkylphenols}

In order to assay alkylphenols in sediment samples, the following reagents were used: water, acetonitrile, methanol HPLC grade (Merck), chloric acid (VII) and ammonium acetate (analytically pure) (POCh), and high grade standards (97\%) of the analysed alkylphenols such as 4-nonylphenol and 4-tert-octylphenol (SIGMA-Aldrich). For the determination of physico-

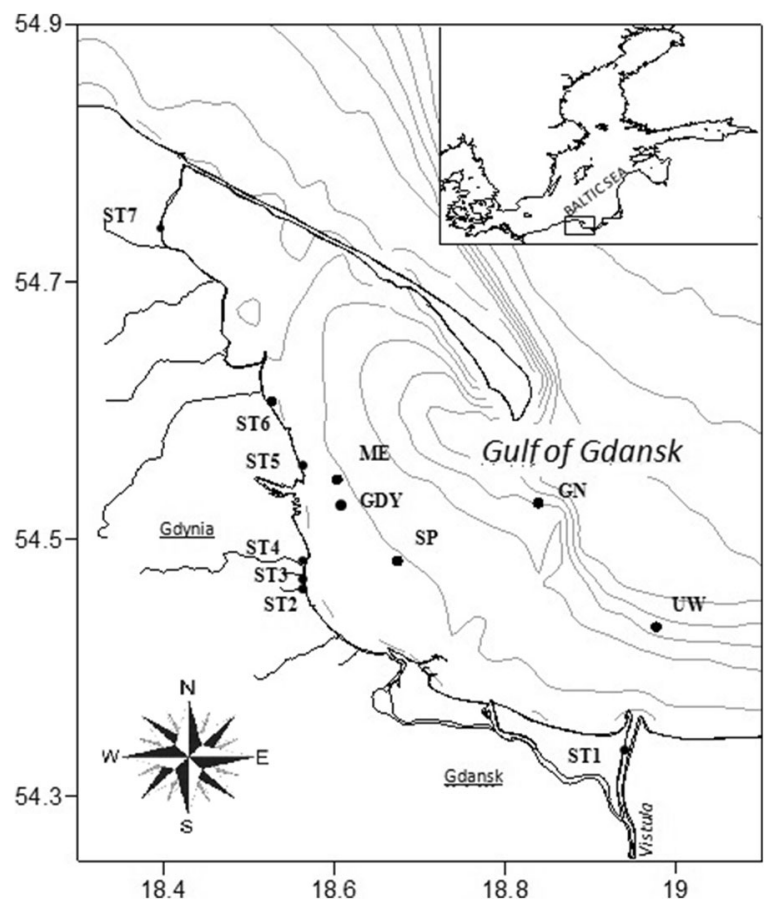

Fig. 1 The locations of sediment sampling sites in the Gulf of Gdansk in 2011-2012 
chemical properties, a solution of $1 \mathrm{M}$ hydrochloric acid and deionised water was used.

Lyophilised sediment samples (2 g) for alkylphenols assay were extracted twice for $15 \mathrm{~min}$ using $5 \mathrm{~cm}^{3}$ of a 30:70 mixture of deionised water and methanol. The obtained extractions were purified on SPE C18 columns using a method developed by Nunez et al. (2007). Elution was carried out three times with $1 \mathrm{~cm}^{3}$ of methanol and $1 \mathrm{~cm}^{3}$ of acetonitrile. The extracts were then dried by evaporation using a rotary evaporator and reconstituted in $200 \mu \mathrm{dm}^{3}$ of acetonitrile.

The final analysis of alkylphenols in sediments was conducted using a high-performance liquid chromatograph Dionex UltiMate 3000 with a fluorescence detector (excitation $\lambda=275 \mathrm{~nm}$, emission $\lambda=300 \mathrm{~nm}$ ) and a Thermo Scientific HYPERSIL GOLD C18 PAH chromatography column $(250 \times 4.6 \mathrm{~mm}, 5 \mu \mathrm{m})$ in the mobile phase programme (water/acetonitrile) in gradient conditions.

\subsection{Validation Parameters}

The linear correlation coefficient $r$ in the analytical curves of working solutions with concentrations of $10,25,50,75$ and $100 \mathrm{ng} \mathrm{cm}{ }^{-3}$ was higher than 0.999. The limit of quantification (LOQ) was $0.08 \mathrm{ng} \cdot \mathrm{g}^{-1} \mathrm{dw}$ for 4-nonylphenol and 4-tertoctylphenol. The background value was below quantification level. Mean recovery of both studied compounds in a sediment sample with a known amount of the standard was 94 and $81 \%$ for 4 tert-octylphenol and 4-nonylphenol, respectively. Precision, expressed by the relative standard deviation coefficient (RSD) for five repetitions of the same sample, was below $8 \%$ for each of the compounds.

\subsection{Statistical Analysis and Data Normalisation}

The statistical analysis and a visual representation of the obtained results were carried out using the STATISTICA 10 programme by Stat Soft. The normality of data distribution was checked using the Shapiro-Wilk test $(p<0.05)$. Most results were of a non-parametric nature. The dependences were determined using the Spearman's Rho correlation coefficient, adopting a confidence interval of $95 \%$.
NP and OP concentrations were normalised to the smallest fraction of sediment $(\varnothing<0.063 \mathrm{~mm})$ using the following formula (Beldowski and Pempkowiak 2007):

$\mathrm{APs}_{\phi}=\frac{[\mathrm{APs}]}{10^{-2} \circ \phi<0.063 \mathrm{~mm}}$

$\operatorname{APs}_{\varnothing} \quad$ concentration of alkylphenols normalised to the smallest sediment fraction

APs alkylphenol concentration

$\varnothing \quad$ diameter of sediment particles

\section{Results and Discussion}

\subsection{4-tert-octylphenol and 4-nonylphenol Concentrations}

The mean value for 4-nonylphenol concentrations determined in the sediments of the Gulf of Gdansk amounted to $6.96 \mathrm{ng} \mathrm{g}^{-1} \mathrm{dw}$ (Table 2), and this is comparable to concentrations obtained in other coastal areas of Europe. In 2003, Jonkers et al. found a mean NP concentration of $5.6 \mathrm{ng} \mathrm{g}^{-1} \mathrm{dw}$ in the Scheldt and Rhine river estuaries (Holland), while similar values were found in sediment from Barcelona harbour (Spain) (9.25 $\mathrm{ng} \mathrm{g}^{-1} \mathrm{dw}$ ) (Petrovic et al. 2002). However, the mean NP concentration in sediment from the German coast (North Sea) amounted to $32.5 \mathrm{ng} \mathrm{g}^{-1} \mathrm{dw}$ (Bester et al. 2001). NP concentration levels in Asia were even higher than in Europe, reaching $64.5 \mathrm{ng} \mathrm{g}^{-1} \mathrm{dw}$ in the sediments of the Sea of Japan (Hong and Shin 2009) and as much as $1.22 \mu \mathrm{g} \mathrm{g}^{-1} \mathrm{dw}$ in sediments from the Yundang Lagoon in China (Zhang et al. 2011). In Jamaica Bay, near New York (USA), sediments exposed to pollution through petroleum recovery were characterised by average NP concentrations that were over 100-fold higher (846 $\mathrm{ng} \mathrm{g}^{-1} \mathrm{dw}$ ) (Lee Ferguson et al. 2001) than those found in the sediments of the Gulf of Gdansk (Fig. 2).

Mean OP concentration in the sediments of the Gulf of Gdansk amounted to $7.46 \mathrm{ng} \mathrm{g}^{-1} \mathrm{dw}$ (Table 2) and was lower than in other regions of the world. Estimated OP levels in sediments from the Thermaic Gulf in Greece were slightly higher at $10.3 \mathrm{ng} \mathrm{g}^{-1} \mathrm{dw}$ (Arditsoglou and Voutsa 2012), but in sediments from the Mediterranean coast of 
Table 2 Characterisation of 4nonylphenol and 4-tertoctylphenol concentration in sediment samples collected in river estuaries (A), at shallow coastal stations (B) and at deeper open water stations $(\mathrm{C})$
Sampling station/variable

4-nonylphenol

[ng g ${ }^{-1} \mathrm{dw}$ ]

4-tert-octylphenol [ng g ${ }^{-1} \mathrm{dw}$ ]

\begin{tabular}{|c|c|c|c|}
\hline \multicolumn{4}{|c|}{ A. Rivers } \\
\hline & & Min-max & Min-max \\
\hline ST6 & Gizdepka River & $<\mathrm{LOQ}-4.93$ & $0.55-47.12$ \\
\hline ST2 & Kacza River & $<\mathrm{LOQ}-2.21$ & $<$ LOQ -8.51 \\
\hline ST1 & Vistula Swibno & $<\mathrm{LOQ}-4.44$ & $<$ LOQ -23.43 \\
\hline$n$ & & 18 & 18 \\
\hline$x \pm \mathrm{SD}$ & & $2.26 \pm 1.63$ & $7.58 \pm 13.43$ \\
\hline Median & & 0.63 & 2.71 \\
\hline \multicolumn{4}{|c|}{ B. Coastal station } \\
\hline ST7 & Swarzewo & $<\mathrm{LOQ}-3.13$ & $0.5-48.88$ \\
\hline ST5 & Mechelinki & $<$ LOQ -2.32 & $0.14-38.72$ \\
\hline ST4 & Gdynia Seaside Boulevard & $<\mathrm{LOQ}-13.56$ & $<$ LOQ -18.74 \\
\hline ST3 & Orlowo & $<\mathrm{LOQ}-2.21$ & $0.16-14.90$ \\
\hline$n$ & & 24 & 24 \\
\hline$x \pm \mathrm{SD}$ & & $2.35 \pm 3.38$ & $9.57 \pm 13.45$ \\
\hline Median & & 1.34 & 3.24 \\
\hline \multicolumn{4}{|c|}{ C. Open water stations (depths over $4 \mathrm{~m}$ ) } \\
\hline ME & & $<\mathrm{LOQ}-0.23$ & $0.15-2.45$ \\
\hline SP & & $<\mathrm{LOQ}-2.66$ & $1.02-11.75$ \\
\hline GDY & & $<\mathrm{LOQ}-4.24$ & $0.34-20.47$ \\
\hline GN & & $0.08-3.95$ & $1.77-17.89$ \\
\hline UW & & $<$ LOQ -249.08 & $2.61-18.44$ \\
\hline$n$ & & 30 & 30 \\
\hline$x \pm \mathrm{SD}$ & & $12.58 \pm 52.83$ & $5.30 \pm 5.51$ \\
\hline Median & & 1.06 & 2.61 \\
\hline
\end{tabular}

$n$ sampling number, $x$ mean value, $S D$ standard deviation, $L O Q$ limit of quantification, $\mathrm{LOQ}=$ $0.08 \mathrm{ng} \mathrm{g}^{-1} \mathrm{dw}$ in the Gulf of Gdansk. Bottom sediments from Masan Bay in South Korea were characterised by mean OP concentrations of $91.5 \mathrm{ng} \mathrm{g}^{-1} \mathrm{dw}$ (Khim et al. 1999), and equally high concentrations were discovered in
Spain, OP concentrations were over eight times higher than $61 \mathrm{ng} \mathrm{g}^{-1} \mathrm{dw}$ (Petrovic et al. 2002). As was the case with NP, the concentrations of OP were much higher in the sediments of South-East Asia than

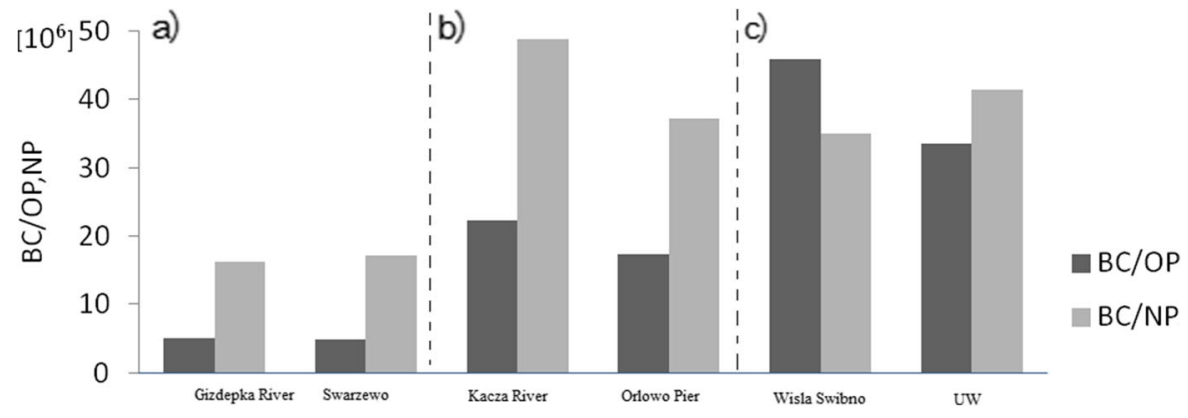

Fig. 2 Proportions of black carbon (BC) to 4-nonylphenol (NP) and 4-tert-octylphenol (OP) in sediments from river stations and stations situated close to river outlets: a Gizdepka River (ST6):
Swarzewo (ST7), b Kacza River (ST4): Orlowo Molo (ST3), c Vistula Swibno (ST1): UW 
bottom sediments on the coast of Taiwan (Cheng et al. 2006).

\subsection{Possible Sources of Alkylphenols in Different Seasons}

On the basis of the obtained results, it was found that rivers are the main transportation route of hydrophobic pollutants related to black carbon into estuaries and coastal areas (Table 2). The same relationship is described by Mannino and Harvey (2004) with respect to the region of Chesapeake Bay by the Delaware estuary. The assays in the Gulf of Gdansk have shown that the relations of black carbon concentrations to 4-tert-octylphenol and 4-nonylphenol concentrations are similar in sediment samples both from river estuaries and stations located close to the outlets of small rivers (Fig. 2).

In each case, the revealed similarities indicated the same source of black carbon on which alkylphenols were sorbed. $\mathrm{BC}$ is a component of a suspension transported by rivers into seas and oceans (Mitra et al. 2002). Another dependency was indicated by the BC/NP ratios at the Vistula estuary station (ST1) and the UW station, located in the same area but further out to sea. The sediment from the latter station (UW) had BC/NP ratios higher than the other stations and the highest NP concentrations (249.08 $\mathrm{ng} \mathrm{g}^{-1} \mathrm{dw}$ ). The differences resulted from the type of sediment (silt sediment); the depth of the station; and the highest content of total carbon (TC), organic carbon (OC) and black carbon (BC) (Table 3).

In the case of 4-tert-octylphenol, its mean concentrations in sediment from estuary stations (A) $\left(7.58 \mathrm{ng} \mathrm{g}^{-1} \mathrm{dw}\right)$ were higher than mean concentrations found in sediments from open water stations (C) (5.31 $\mathrm{ng} \mathrm{g}^{-1} \mathrm{dw}$ ) (Table 3). Similar results were obtained by Zhang et al. (2011), indicating that a significant load of surface active agents containing NP and OP was introduced into the sea via river transportation. In summer, the differences in OP and NP concentrations between the stations of the coastal zone (B) and the open water stations (C) were even more pronounced due to higher water temperature. In that period, the breakdown of alkylphenol etoxylates in the coastal zone occurs more rapidly and can result in an increase in NP and OP concentrations in sediment collected in river estuaries. On the other hand, in deeper waters, where the temperature is lower, etoxylate decomposition may be slower or limited. This is confirmed by results found in literature from around the world. Manzano et al. (1999) discovered that alkylphenol etoxylate breakdown takes place more rapidly at $22.5^{\circ} \mathrm{C}$ than at $13{ }^{\circ} \mathrm{C}$. This was also observed during tests carried out in the Gulf of Gdansk (Fig. 3) as the highest OP and NP concentrations occurred in summer (Fig. 3b). In spring (Fig. 3a), there was probably a second factor which effected an increase in alkylphenol concentrations in river estuary sediment, namely the increased river dynamics of that season causing the resuspension of organic matter containing NP and OP.

At coastal stations (Fig. 4), increased alkylphenol concentrations were influenced by the proximity to beaches and public spaces as well as by high temperature. At those sites, high concentrations of 4-tertoctylphenol were observed (Fig. 4b), and this was probably related to the widespread use of OP in suncreams or other cosmetics and synthetic materials used by tourists.

At open water stations below the 4-m isobath (Fig. 5), the highest concentrations of OP and NP were observed in autumn, and this has to be linked with alkylphenols introduced to surface sediments with suspension about 6 months previously, in springtime (Fig. 5c).

\subsection{Black Carbon Influence}

The dependency between NP and OP concentrations within the smallest sediment fraction in samples from open water stations, located at depths of over $4 \mathrm{~m}$, and the $\mathrm{BC} / \mathrm{OC}$ ratio was indicated by high correlation coefficients (NP $r=0.70$, $p=0.02$; OP $r=0.75, p=0.02$ ). In terms of the occurrence of seasonal changes in alkylphenol concentrations, a strong correlation was observed only in sediments collected in autumn ( $r=0.89$ for NP and $r=0.94$ for OP, $p<0.03$ ).

Owing to the fact that autumn is a time when fossil fuel combustion increases in thermal-electric power stations and individual households, it should be expected that atmospheric deposition plays at that time a significant role in delivering $\mathrm{BC}$, accompanied by alkylphenols, to surface waters. Another way in which $\mathrm{BC}$ enters the environment is through biomass combustion. Although most $\mathrm{BC}$ is deposited close to emission sites, its transportation via rivers and the atmosphere is also possible (Mannino and Harvey 2004). This is confirmed by results presented in a publication prepared by Lewandowska et al. (2012), which show that alkylphenols can be found in small aerosols (PM1 and PM2), closely correlated with the presence of BC. The highest OP and NP concentrations in small aerosols were determined in autumn and winter, that is, during 
Table 3 Characterisation of physicochemical properties of surface sediments collected in river estuaries (A), in the coastal zone (B) and at stations located some distance away from the coast below the 4-m isobath (C)

\begin{tabular}{|c|c|c|c|c|c|c|c|}
\hline \multicolumn{2}{|c|}{ Sampling station/variable } & $\mathrm{W}[\%]$ & LOI $[\%]$ & $\mathrm{TC}[\%]$ & $\mathrm{OC}[\%]$ & $\mathrm{BC}[\%]$ & Type of sediment \\
\hline \multicolumn{8}{|c|}{ Min-max } \\
\hline \multicolumn{8}{|c|}{ A. Rivers } \\
\hline ST6 & Gizdepka River & $12.6-26.1$ & $0.3-0.8$ & $0.087-0.455$ & $0.017-0.580$ & $0.007-0.035$ & Medium sand \\
\hline ST2 & Kacza River & $12.5-17.8$ & $0.5-21.6$ & $0.170-0.515$ & $0.040-0.226$ & $0.068-0.087$ & Pebbles \\
\hline ST1 & Vistula Swibno & $18.0-22.2$ & $0.3-6.2$ & $0.140-0.301$ & $0.051-0.158$ & $0.027-0.047$ & Silt \\
\hline \multicolumn{8}{|c|}{ B. Coastal station } \\
\hline ST7 & Swarzewo & $20.3-30.4$ & $0.4-2.7$ & $0.152-0.782$ & $0.033-0.568$ & $0.003-0.071$ & Medium sand \\
\hline ST5 & Mechelinki & $12.8-21.6$ & $0.1-0.5$ & $0.156-0.603$ & $0.019-0.053$ & $0.025-0.091$ & Coarse sand \\
\hline ST4 & Gdynia Seaside Boulevard & $7.0-18.5$ & $0.3-0.8$ & $0.133-0.610$ & $0.017-0.070$ & $0.002-0.097$ & Coarse sand \\
\hline ST3 & Orlowo Pier & $16.3-19.9$ & $0.2-6.1$ & $0.070-0.249$ & $0.006-0.065$ & $0.001-0.062$ & Medium sand \\
\hline \multicolumn{8}{|c|}{ C. Station below $4 \mathrm{~m}$ depth } \\
\hline \multicolumn{2}{|l|}{ ME } & $13.9-21.7$ & $0.4-13.5$ & $0.102-0.336$ & $0.047-0.107$ & $0.008-0.047$ & Medium sand \\
\hline \multicolumn{2}{|l|}{ SP } & $16.1-23.4$ & $0.3-1.1$ & $0.008-0.402$ & $0.065-0.364$ & $0.013-0.030$ & Medium sand \\
\hline \multicolumn{2}{|l|}{ GDY } & $14.7-61.8$ & $0.4-11.1$ & $0.142-3.189$ & $0.092-2.577$ & $0.002-0.252$ & Medium sand \\
\hline \multicolumn{2}{|l|}{ GN } & $17.0-34.0$ & $0.4-2.7$ & $0.235-2.027$ & $0.121-1.450$ & $0.009-0.215$ & Silt \\
\hline \multicolumn{2}{|l|}{ UW } & $17.1-63.0$ & $0.4-16.6$ & $0.101-3.331$ & $0.070-2.742$ & $0.010-0.271$ & Silt \\
\hline
\end{tabular}

$W$ wetness, $L O I$ loss of ignitron, $T C$ total carbon, $B C$ black car bon, $O C$ organic carbon

the heating season. In these seasons, additionally, it is dominated by air mass paths from sectors: $\mathrm{S}$ and SW caring heating contaminations and BC from surrounding villages (Staniszewska et al. 2013).

The results obtained in the Gulf of Gdansk are also confirmed by publications where the authors indicate the possibility of atmospheric transportation and deposition of black carbon and alkylphenol into surface waters (Xie et al. 2006). Black carbon is the most important aerosol component, influencing the sorption of hydrophobic pollutants deposited on the surface of sediments (Staniszewska et al. 2011). Owing to the dependency between $\mathrm{NP}$ and $\mathrm{OP}$ and the $\mathrm{BC} / \mathrm{OC}$ ratio within the smallest sediment particles, atmospheric
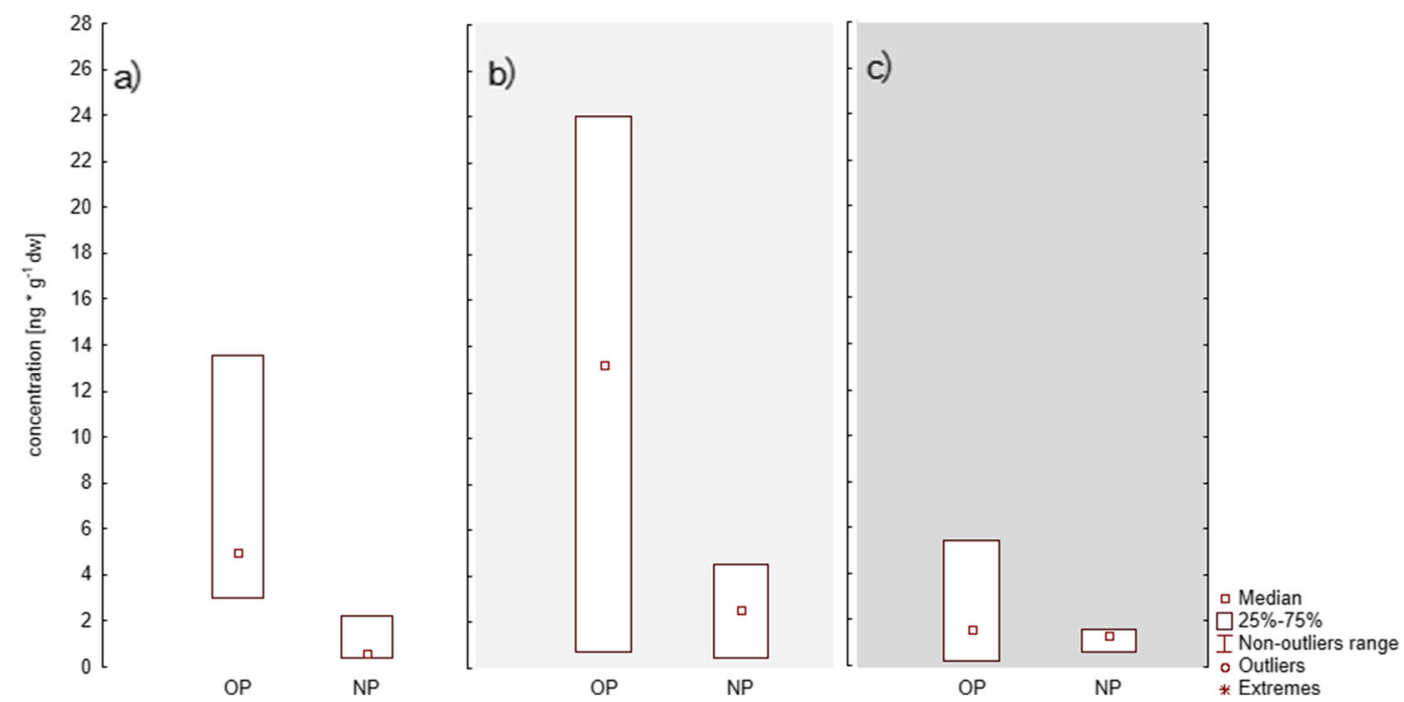

Fig. 3 Seasonal changes in 4-nonylphenol (NP) and 4-tert-octylphenol (OP) in sediments from river stations ST1, ST2, ST6 in a spring, b summer and c autumn 

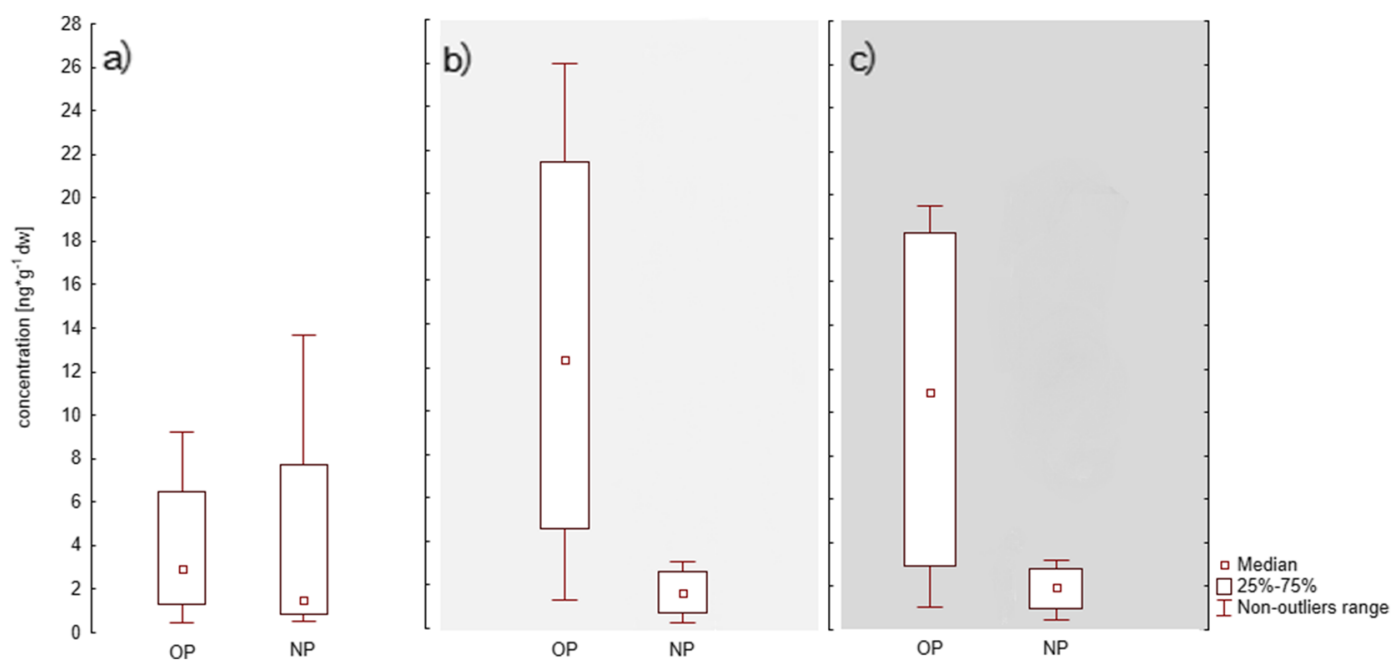

Fig. 4 Seasonal changes in 4-nonylphenol (NP) and 4-tert-octylphenol (OP) in sediments from coastal stations ST3, ST4, ST5, ST7 in a spring, b summer and $\mathbf{c}$ autumn

deposition can be considered a very likely source of alkylphenols.

\subsection{Sorptive Properties of 4-nonylphenol and 4-tert-octylphenol}

4-tert-octylphenol had higher concentrations in sediments than 4-nonylphenol. This was undoubtedly influenced by the widespread use of OP in industry and the lack of legal restrictions in the EU. OPs are used mainly as additives to synthetic materials, serving as glue or binding agents during emulsion polymerisation.
Octylphenol etoxylates are used in the production of textiles covered with a thin polymer film that makes the material more resistant to water, dust and light, and gives it a glossy look (e.g. leather). They are also used in the production of cosmetics (HELCOM 2011). An increased amount of surface active agents can alter the sorptive properties of sediments, which in turn can cause changes in the distribution of various hydrophobic substances (Yang et al. 2011).

Another factor influencing the occurrence of higher concentrations of OP than NP is OP's greater residence time in the environment. OP has a different, more
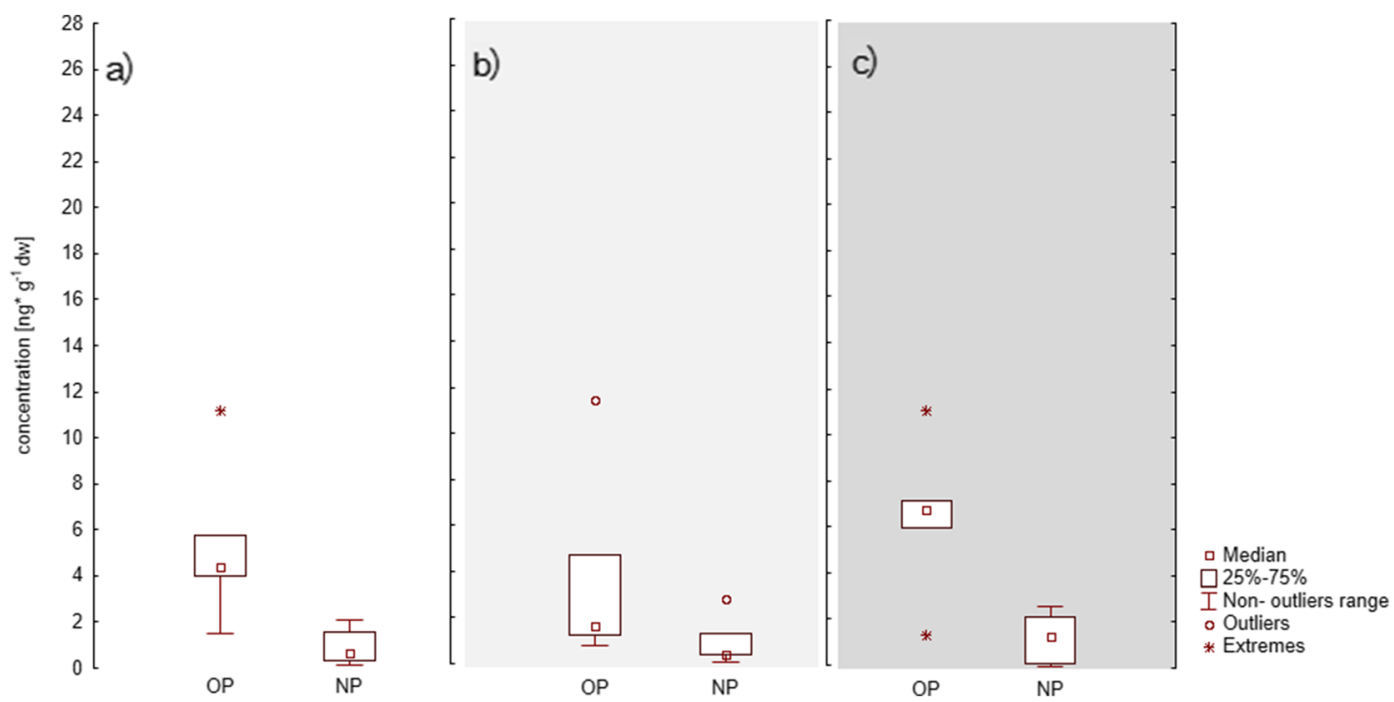

Fig. 5 Seasonal changes in 4-nonylphenol (NP) and 4-tert-octylphenol (OP) in sediments from open water stations located below the 4-m isobath ME, SP, GDY, GN, UW in a spring, b summer and $\mathbf{c}$ autumn 
branched out, hydrocarbon chain structure than NP (Pignatello 1998) (Fig. 6). Owing to that, its residence time in the environment is longer as the decomposition process is slower. The sediments of the Gulf of Gdansk are often short in oxygen, which can result in the breakdown of alkylphenol etoxylates becoming decelerated (Falkowska et al. 1993). At stations situated in deeper water, OP concentrations were nevertheless lower than in the coastal area. Despite its long residence time, OP was not strongly connected to sediment. This is confirmed by a lack of correlation between OP concentration and carbon forms (TC, OC and BC). However, such correlations were observed for 4-nonylphenol $(0.76>r>$ 0.96, $p<0.03$ ). According to Heinis et al. (1999), the half-life time for 4-nonylphenol in anaerobic conditions is 66 days, while 401 days are required for a complete breakdown of this compound and $95 \%$ of its removal. When oxygen is involved, the decomposition of 4nonylphenol occurs more rapidly, with nearly $50 \%$ of this compound decomposing within 10 days (Ying et al. 2003). Having a linear hydrocarbon chain structure, 4nonylphenol becomes more easily sorbed onto sediment particles (Fig. 6). This compound is characterised by higher values of $K_{\mathrm{o} / \mathrm{c}}$ coefficient (38.90 thousand $\mathrm{dm}^{3}$. $\mathrm{kg}^{-1}$ ) and $K_{\mathrm{o} / \mathrm{w}}$ coefficient (4.48) than is the case with 4tert-octylphenol $\left(K_{\mathrm{o} / \mathrm{w}}=4.12, K_{\mathrm{o} / \mathrm{c}}=18.20\right.$ thousand $\left.\mathrm{dm}^{3} \cdot \mathrm{kg}^{-1}\right)$.

\section{Risk to the Marine Environment}

Alkylphenols accumulated in sediments may have a negative effect on benthic organisms, especially silteating ones, at a low level of the trophic chain. According to US EPA, the indicator of alkylphenol noxiousness for benthic organisms is PNEC (predicted no effect concentration), which signifies the concentration level below which there are no harmful consequences for the environment. 4-tert-octylphenol a)

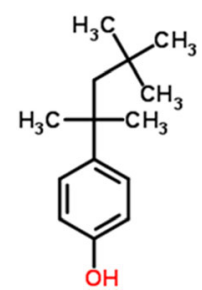

b)

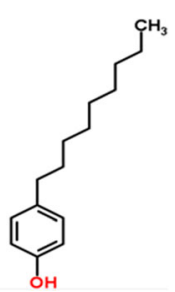

Fig. 6 Structural composition of a OP and $\mathbf{b}$ NP concentrations exceeded the EPA-adopted PNEC value by $8 \%$ and 4 -nonylphenol by $3 \%$ at $34 \mathrm{ng} \mathrm{g}^{-1} \mathrm{dw}$ for OP and $170 \mathrm{ng} \mathrm{g}^{-1} \mathrm{dw}$ for NP. It can therefore be said that the sediments of the Gulf of Gdansk are not badly polluted with alkylphenols. A greater number of exceedances were observed in sediments from the Gulf of Finland, the Danish straits and the Northern part of Baltic Proper (HELCOM 2010).

\section{Summary}

The increasingly widespread use of alkylphenols in European industry has led to these compounds being found in measurable concentration levels in surface sediments of the Gulf of Gdansk. 4-nonylphenol and 4-tert-octylphenol concentrations were comparable to other coastal regions of Europe, but much lower, even by several orders of magnitude, than in sea sediment from the regions of South-East Asia. Increased concentrations in sediments, mainly in the coastal zone, were found particularly in summertime, when at higher water temperatures the decomposition of alkylphenol precursors (etoxylates) occurred more rapidly. Well-developed tourism and increased recreation in the coastal area, especially during summer, result in a higher consumption of products containing alkylphenols. In spring, high 4-nonylphenol and 4-tert-octylphenol concentrations arrived in the coastal zone with meltwater.

The obtained results have shown that rivers and surface run-off are the main sources of alkylphenols in coastal sediments of the Gulf of Gdansk, whereas the role of the atmosphere as a means of alkylphenol transportation over the sea increases in significance mainly in autumn. The high correlation coefficients found between NP and OP concentrations and the $\mathrm{BC} / \mathrm{OC}$ ratio confirm the significance of black carbon originating from combustion processes on land as a factor of alkylphenol distribution in the environment.

Acknowledgments This research was finance by the National Science Centre and Polish Ministry of Science and Higher Education within Framework of the Project No N N 305106840.

Open Access This article is distributed under the terms of the Creative Commons Attribution License which permits any use, distribution, and reproduction in any medium, provided the original author(s) and the source are credited. 


\section{References}

Arditsoglou, A., \& Voutsa, D. (2012). Occurrence and partitioning of endocrine-disrupting compounds in the marine environment of Thermaikos Gulf, Northern Aegean Sea, Greece. Marine Pollution Bulletin, 64, 2443-2452.

Beldowski, J., \& Pempkowiak, J. (2007). Mercury transformations in marine coastal sediment as derived from mercury transformation and speciation changes along source/sink transport pathway (Southern Baltic). Estuarine, Coastal and Shelf Science, 72, 370-378.

Bester, K., Theobald, N., \& Schroder, H. F. (2001). Nonylphenols, nonylphenol-ethoxylates, linear alkylbenzene sulfonates (LAS) and bis(4-chlorophenyl)-sulfone in the German Bigt of the North Sea. Chemosphere, 45, 817-826.

Cheng, C. Y., Liu, L. L., \& Ding, W. H. (2006). Occurrence and seasonal variation of alkylphenols in marine organisms from the coast of Taiwan. Chemosphere, 65, 2152-2159.

Falkowska, L., Bolalek, J., \& Nowacki, J. (1993). Nutrients and oxygen in the Gulf of Gdansk. Studia $i$ Materialy Oceanologiczne, 64, 131-162.

Flint, S., Markle, T., Thompson, S., \& Wallace, E. (2012). Bisphenol A exposure, effects, and policy: a wildlife perspective. Review. Journal of Environmental Management, 104, 19-34.

Gustafsson, O., Haghseta, F., Chan, C., MacFarlane, J., \& Gschwend, P. M. (1997). Quantification of the dilute sedimentary soot phase: implications for PAH speciation and bioavailability. Environmental Science and Technology, 31, 203-209.

Hedges, J. I., \& Stern, J. H. (1984). Carbon and nitrogen determinations of carbonate-containing solids. Limnology and Oceanography, 29, 657-663.

Heinis, L. J., Knuth, M. L., Liber, K., Sheedy, B. R., Tunell, R. L., \& Ankley, G. T. (1999). Persistence and distribution of 4nonylphenol following repeated application to littoral enclosures. Environmental Toxicology and Chemistry, 18, 363375.

Heiri, O., Lotter, A. F., \& Lemcke, G. (2001). Loss-on-ignition as a method for estimating organic and carbonate content in sediments: reproducibility and comparability of results. Journal of Paleolimnology, 25, 101-110.

HELCOM. (2010). Hazardous substances in the Baltic Sea. Finland: Erweko Oy.

HELCOM. (2011). Cohiba guidance document no7. Measures for emission reduction of octylphenol (OP) and octylphenol ethoxylates (OPE) in the Baltic Sea Area. Finland.

Hong, S., \& Shin, K.-H. (2009). Alkylphenols in the core sediment of a waste dumpsite in the East Sea (Sea of Japan), Korea. Marine Pollution Bulletin, 58, 1566-1587.

Khim, J. S., Kannan, K., Villeneuve, D. L., Koh, C. H., \& Giesy, J. P. (1999). Characterization and distribution of trace organic contaminants in sediment from Masan Bay, Korea. 1. Instrument analysis. Environmental Science and Technology, 33, 4199-4205.

Lee Ferguson, P., Iden, C. R., \& Brownawell, B. J. (2001). Distribution and fate of neutral alkylphenol ethoxylate metabolites in sewage-impacted urban estuary. Environmental Science and Technology, 35, 2428-2435.
Lewandowska A., Staniszewska M., Falkowska L., Witkowska A., Bełdowska M., Machuta M., Mróz D. (2012). Elemental and organic carbon, benzo(a)pyrene and alkyl-phenols as a function of aerosol particle size in urbanized coastal zone of the Gulf of Gdansk. In J. Konieczyński (Ed.), OCHRONA POWIETRZA W TEORII I PRAKTYCE, IETU PAS, Zakopane, Poland, 14-16.10. 13 p.

Mannino, A., \& Harvey, H. R. (2004). Black carbon in estuarine and coastal ocean dissolved organic matter. Limnology and Oceanography, 49, 735-740.

Manzano, M. A., Perales, J. A., Sales, D., \& Quiroga, J. M. (1999). The effect of temperature on the biodegradation of a nonylphenol polyethoxylate in river water. Water Research, 33, 2593-2600

Markey, C., Michaelson, C., Sonnenschein, C., Soto, A. (2001). Alkylphenols and bisphenol a as environmental estrogens, the handbook of environmental chemistry vol. 3, part L endocrine disruptors, Berlin.

Mitra, S., Bianchi, T. S., McKee, B. A., \& Sutula, M. (2002). Black carbon from the Mississippi River: quantities, sources, and potential implications for the global carbon cycle. Environmental Science and Technology, 36, 2296-2302.

Nunez, L., Turiel, E., \& Tadeo, J. L. (2007). Determination of nonylphenol and nonylphenol ethoxylates in environmental solid samples by ultrasonic-assisted extraction and high performance liquid chromatography-fluorescence detection. Journal of Chromatography, 1146, 157-163.

Petrovic, M., Fernández-Alba, A. R., Borrull, F., Marce, R. M., González, M. E., \& Barceló, D. (2002). Occurrence and distribution of nonionic surfactants, their degradation products, and linear alkylbenzene sulfonates in coastal waters and sediments in Spain. Environmental Toxicology and Chemistry, 1, 37-46.

Pignatello, J. (1998). Soil organic matter as a nanoporous sorbent of organic pollutants. Advances in Colloid and Interface Science, 76-77, 445-467.

Servos, M. (1999). Review of aquatic toxicity, estrogenic responses and bioaccumulation of alkylphenols and alkylphenol polyethoxylates. Water Quality Research Journal, 34, 123-177.

Staniszewska, M., \& Falkowska, L. (2011). Nonylphenol and 4tert-octylphenol in the Gulf of Gdańsk coastal zone. Oceanological and Hydrobiological Studies, 40, 49-56.

Staniszewska, M., Burska, D., Sapota, G., Bogdaniuk, M., Borowiec, K., Nosarzewska, I., \& Bolalek, J. (2011). Black carbon in relation to the content and distribution of organic pollutants in benthic sediments in the Gulf of Gdansk, Baltic Sea. Marine Pollution Bulletin, 62, 1464-1475.

Staniszewska, M., Graca, B., Bełdowska, M., \& Saniewska, D. (2013). Factors controlling benzo(a)pyrene concentration in aerosols in the urbanized coastal zone. A case study: Gdynia, Poland (Southern Baltic Sea). Environmental Science and Pollution Research, 20(6), 4154-4163.

Staniszewska, M., Falkowska, L., Grabowski, P., Kwaśniak, J., Mudrak-Cegiołka, S., Reindl, A. R., Sokołowski, A., Szumiło, E., \& Zgrundo, A. (2014). Bisphenol A, 4-tertoctylphenol, 4-nonylphenol in the Gulf of Gdansk (Southern Baltic). Archives of Environmental Contamination and Toxicology. doi:10.1007/s00244-014-0023-9. 
US EPA. (2010). Nonylphenol (NP) and nonylphenol ethoxylates (NPEs) action plan.

Xie, Z., Lakaschus, S., Ebinghaus, R., Caba, A., \& Ruck, W. (2006). Atmospheric concentrations and air-sea exchanges of nonylphenol, tertiary octylphenol and nonylphenol monoethoxylate in the North Sea. Environmental Pollution, 142, 170-180.

Yang, G.-P., Ding, H.-Y., Cao, X.-Y., \& Ding, Q.-Y. (2011). Sorption behavior of nonylphenol on marine sediments: effect of temperature, medium, sediment organic carbon and surfactant. Marine Pollution Bulletin, 62, 2362-2369.

Ying, G., Kookana, R. S., \& Dillon, P. (2003). Sorption and degradation of selected five endocrine disrupting chemicals in aquifer material. Water Research, 37, 3785-3791.

Zhang, X., Gao, Y., Qingzhao, L. Q., Li, G., Guo, Q., \& Yan, C. (2011). Estrogenic compounds and estrogenicity in surface water, sediments, and organisms from Yundang Lagoon in Xiamen, China. Archives of Environmental Contamination and Toxicology, 61, 93-100. 